\title{
DESIGN PARTICIPATIVO E INOVAÇÃO SOCIAL: A INFLUÊNCIA DOS FATORES CONTEXTUAIS
}

\author{
Chiara Del Gaudio, Dra. (UNISINOS); Orientador: Alfredo Jefferson de
}

\author{
Oliveira, Dr. (PUC-Rio); Co-orientador: Carlo Franzato, Dr. (UNISINOS)
}

Na última década tem sido amplamente divulgada e compartilhada entre os membros da comunidade do design a ideia de que a ação do designer tem a potencialidade de contribuir na resolução dos problemas que afligem a sociedade contemporânea e na definição de soluções capazes de melhorar os contextos cotidianos de vida da população. De acordo com numerosos estudos, isso é possível por meio da aplicação de processos co-criativos e participativos de design no âmbito social. Consequentemente, abordagens como, por exemplo, o design para inovação social, o design social, o design para a base da pirâmide, entre os outros, têm encontrado ampla difusão recentemente entre novos e futuros designers, assim como entre os profissionais da área. É neste cenário que se insere a tese aqui apresentada e a pesquisa que está na sua base. De fato, esta surgiu do interesse em investigar as potencialidades de ação do designer em contextos sociais frágeis, de conflito e marginalizados para promover e potencializar processos locais de inovação social através de experiências participativas e da estratégia de design. O objetivo era compreender melhor e potencializar esta ação.

Focou-se em contextos sociais frágeis, de conflito e marginalizados pela complexidade destes contextos e pela consequente relevância dos resultados. Com a expressão "contextos sociais frágeis, de conflito e marginalizados" refere-se a contextos que se caracterizam por serem caóticos e hiper politizados, pela falta de segurança pública, pelas divisões sociais, pela insuficiente presença de instituições formais, pelas lutas pelo poder, pela presença de atores com agendas conflituais, pelas condições econômicas e sociais frágeis e por sofrer com a exclusão social.

A fim de alcançar o objetivo apresentado, suces- sivamente a um momento preparatório de revisão teórica com relação ao âmbito da contribuição social do design, às abordagens e práticas mais conhecidas e ao contexto selecionado, foi desenvolvido um estudo de caso. No especifico, foi implementado um projeto de design participativo em uma favela carioca - o Complexo de Favelas da Maré - em colaboração com uma ONG local. O projeto A praça que nós queremos aconteceu entre Março e Outubro de 2012 e consistiu no redesign de uma praça local abandonada junto aos habitantes do entorno e a ONG parceira. O objetivo era promover a regeneração urbana do contexto por meio da promoção de dinâmicas democráticas.

Ao longo do seu desenvolvimento foram coletados dados usando como estratégia a observação participante. Sucessivamente, os dados foram codificados e analisados. Foram identificadas duas macro categorias de investigação relativas a questões fundamentais para o tipo de ação de design considerada. Sucessivamente, as macro categorias foram verificadas, compreendidas e detalhadas através de entrevistas com designers especialistas no assunto e de uma nova fase de revisão teórica. Tudo isso permitiu a identificação de duas questões - resultados da pesquisa - que podem influenciar o processo de design, obstaculizá-lo ou até impedi-lo. A primeira é o tempo. Este se apresentou com fator determinante em um projeto de design, pois podem ocorrer divergências temporais entre o designer e o processo de design, entre o contexto e os parceiros de projeto capazes de obstaculizar o projeto. A segunda é a influência das forças contextuais exercidas pelos atores locais sobre as ações do designer e a sua relação com a estrutura da rede de projeto. Os resultados evidenciaram a influência dos fatores contextuais no processo de 
design de projetos participativos que visam promover processos locais de inovação social. As metodologias e ferramentas desenvolvidas até então não são suficientes para este tipo de ação, que se beneficiaria de abordagens que considerem os fatores apresentados. Finalmente, a tese promove uma reflexão sobre a proposta de um design social eficaz e sobre a atual formação em design neste âmbito.
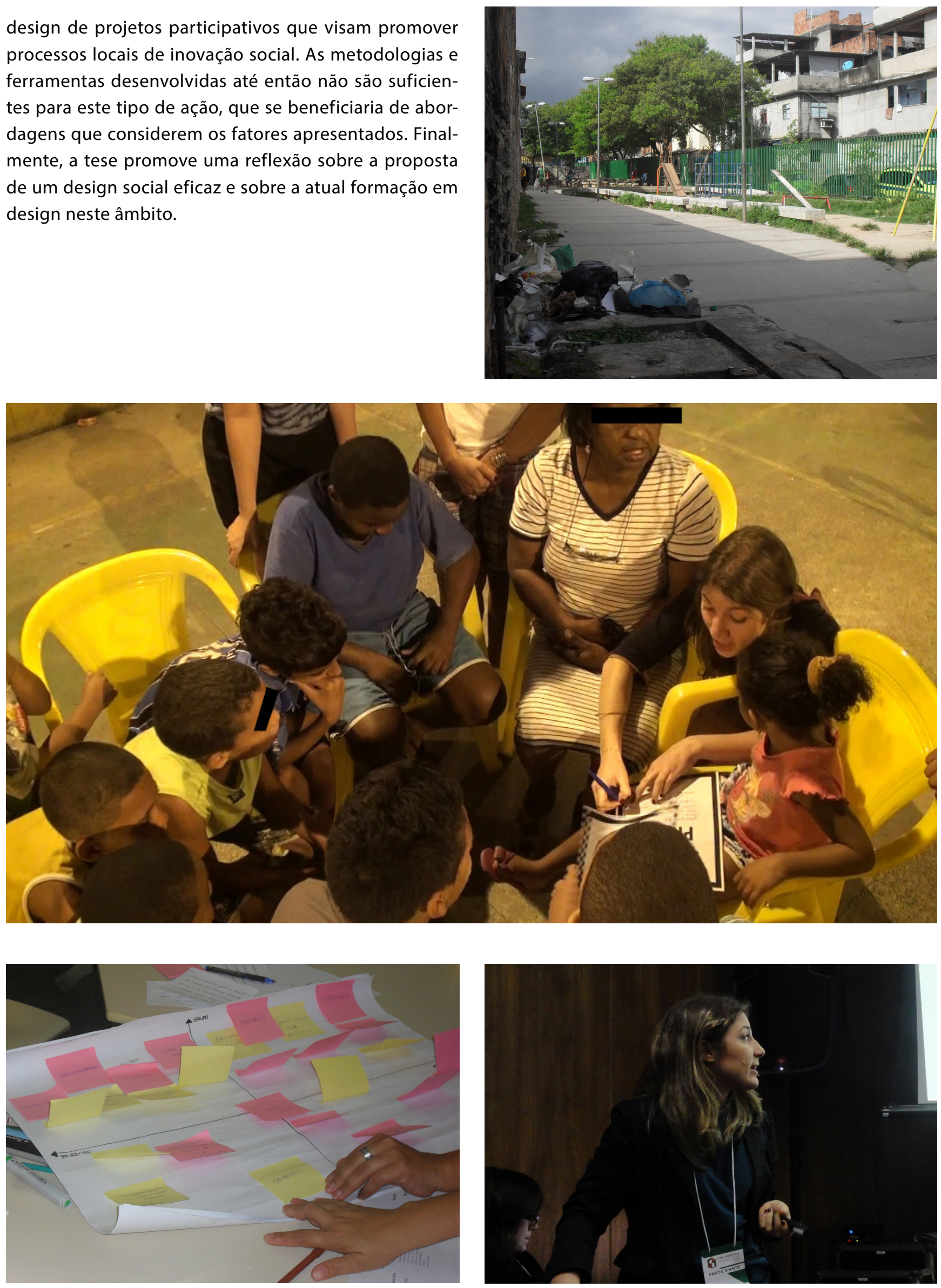